\title{
Influence of culture conditions on the production of extracellular polymeric substances (EPS) by Arthrospira platensis
}

\author{
Mariana B. F. Silva ${ }^{1 *} \mathbb{D}$, Edwin G. Azero², Cláudia M. L. L. Teixeira ${ }^{3}$ and Cristina T. Andrade ${ }^{1,4}$
}

\begin{abstract}
Arthrospira platensis is a cyanobacterium that is of great biotechnological interest, particularly for the food industry, as it possesses a high content of proteins, pigments, lipids and carbohydrates. Cyanobacteria produce extracellular polymeric substances (EPS), which are co-products of secondary metabolism that present thickening or gelling properties. A 3-level factorial design was used to study the combined effect of different nitrate concentrations and photon flux density (PFD) values to evaluate the biomass and EPS production of $A$. platensis. The best result in terms of biomass production was obtained under condition $6\left(2 \mathrm{~g} \mathrm{~L}^{-1} \mathrm{NaNO}_{3}\right.$ and $\left.600 \mathrm{\mu E} \mathrm{m}^{-2} \mathrm{~s}^{-1}\right)$ yielding a concentration of $1.292 \mathrm{~g} \mathrm{~L}^{-1}$. However, condition $1\left(0.25 \mathrm{~g} \mathrm{~L}^{-1} \mathrm{NaNO}_{3}\right.$ and $\left.200 \mu \mathrm{E} \mathrm{m}^{-2} \mathrm{~s}^{-1}\right)$ produced the greatest EPS yield $\left(111 \mathrm{mg} \mathrm{g}^{-1}\right)$, followed by condition $9\left(2 \mathrm{~g} \mathrm{~L}^{-1} \mathrm{NaNO}_{3}\right.$ and $\left.1000 \mu \mathrm{E} \mathrm{m}^{-2} \mathrm{~s}^{-1}\right)$. FTIR analyses of EPS samples indicated the presence of carboxylate and sulfate functional groups, and rheological studies of the EPS at 5 and $10 \mathrm{~g} \mathrm{~L}^{-1}$ revealed a dilute solution behavior.
\end{abstract}

Keywords: Arthrospira platensis, Cyanobacteria, Extracellular polymeric substances

\section{Introduction}

The phylum of cyanobacteria comprises a group of diverse prokaryotes. These microorganisms typically use autotrophic metabolism, but can also be grown in heterotrophic and mixotrophic conditions, and are commonly found in brackish or marine environments (Baldev et al. 2015). They are responsible for the incorporation of a large proportion of atmospheric $\mathrm{CO}_{2}$ and some of them are $\mathrm{N}_{2}$ fixers (Oliver and Atsumi 2014). Cyanobacteria produce extracellular polymeric substances (EPS), which have a protective function in biofilm formation, a mechanical barrier against desiccation (Decho and Gutierrez 2017), and which also aids in the absorption of heavy metals (Goo et al. 2013). The composition of EPS depends on the species. Generally, they are formed by

\footnotetext{
*Correspondence: mariana_barbalho@ufrj.br

1 Programa de Pós-Graduação em Ciência de Alimentos, Instituto de Química, Universidade Federal do Rio de Janeiro, Avenida Athos da Silveira Ramos 149, Rio de Janeiro, RJ 21941-909, Brazil

Full list of author information is available at the end of the article
}

various substances, such as proteins, polysaccharides, lipids, humic-like substances, DNA, lipopolysaccharides and glycoprotein heteropolymers (Can et al. 2019). EPS may be entirely released into the extracellular environment or may be associated with the cell surface as sheaths, capsules or slime (Pereira et al. 2009).

EPS have attracted industrial interest because of their polyanionic character and that they are a renewable source. They can be used as thickeners, emulsifying agents and biosurfactants, with applications in the food and biomedical industry. Antibacterial (Mundt et al. 2001), antioxidant (Trabelsi et al. 2016) and anti-inflammatory properties (Xiao et al. 2018) have already been reported for EPS of cyanobacteria.

Arthrospira platensis, also called Spirulina platensis, is a filamentous blue-green cyanobacterium, belonging to the order Cyanophyceae, division Cyanophyta (Manirafasha et al. 2018). Its biomass is used in human food due to its high protein content (approximately $70 \%$ of dry weight). It also produces pigments such as carotenoids and phycocyanin, polyunsaturated fatty acids, several 
vitamins, minerals and other constituents with antioxidant activity (Gong et al. 2008; Shabana et al. 2017). Sulfated heteropolysaccharides, frequently formed by neutral (xylose, galactose, glucose, fructose, rhamnose, arabinose and mannose) and uronic acid (galacturonic and glucuronic acids) repeating units, have been identified in the EPS of this species (Trabelsi et al. 2009a). Literature reviews suggest that the EPS from A. platensis have specific properties, which may contribute to human health. A fraction containing sulfated polysaccharides, at concentrations between 18 and $36 \mu \mathrm{g} \mathrm{mL}^{-1}$, was shown to inhibit the replication of Koi herpes virus (Reichert et al. 2017). Challouf et al. (2011) reported antibacterial activity against Salmonella typhimurium and Staphylococcus epidermis. Furthermore, antioxidant activity of crude EPS was described by Dejsungkranont et al. (2017).

Although EPS could contribute to numerous industrial areas, the cost of the current extraction and purification procedures, the low yield and the lack of knowledge regarding their structure impede their commercial use at this time. In order to minimize costs and enhance EPS yields, optimization of the culture parameters may be necessary. EPS production by cyanobacteria can be influenced by environmental and nutritional conditions, including temperature (Trabelsi et al. 2009a), photonic flux density (PFD) (Villay et al. 2013) and nitrogen starvation (Arad and Levy 2010). The right combination of these parameters could greatly improve EPS production. However, only a few studies have been conducted with the objective to enhance the EPS yield from species of cyanobacteria. For example, the temperature and PFD parameters were optimized for the production of EPS from Cyanothece sp., with $140 \mathrm{mg} \mathrm{L}^{-1}$ at $30{ }^{\circ} \mathrm{C}$ and $8 \mu \mathrm{E} \mathrm{m}^{-2} \mathrm{~s}^{-1}$, and from Rhodella violacea, with $600 \mathrm{mg} \mathrm{L}^{-1}$ at $24{ }^{\circ} \mathrm{C}$ and $420 \mu \mathrm{E} \mathrm{m}^{-2} \mathrm{~s}^{-1}$ (Ohki et al. 2014; Villay et al. 2013). Whilst for Dunaliella salina and Synechocystis sp., the optimization of the required $\mathrm{NaCl}$ concentration was investigated, reaching EPS yields of $944 \mathrm{mg} \mathrm{L}^{-1}$ and $630 \mathrm{mg} \mathrm{L}^{-1}$, respectively (Mishra and Jha 2009; Ozturk and Aslim 2010). Using A. platensis, factors of temperature, PFD and the concentrations of $\mathrm{NaCl}$ and $\mathrm{NaNO}_{3}$ have been studied individually or in combination by Trabelsi et al. (2009b), Chentir et al. (2017) and Dejsungkranont et al. (2017), producing maximum yields of $210 \mathrm{mg} \mathrm{L}^{-1}, 0.98 \mathrm{~g} \mathrm{~g}^{-1}$ and $772.1 \pm 192.9 \mathrm{mg} \mathrm{g}^{-1}$, respectively.

The determination of the best techniques to extract and purify the EPS, as well as the full characterization of the resulting product, could also bring it closer to industrial use (Delattre et al. 2016). In general, the culture medium of the cyanobacteria is centrifuged or filtrated to remove the cells and then the supernatant or filtrate is concentrated to reduce the water content. Some authors have employed the use of a heat bath (Parikh and Madamwar 2006) or a process using a membrane, such as tangential ultrafiltration (Han et al. 2014) or microfiltration (Ahmed et al. 2014), to attain the concentrate. However, membrane processing depends on the viscosity of the culture medium, pore size distribution and transmembrane pressure (Li et al. 2012). The most frequently used technique to recover the EPS from the concentrate is by alcohol precipitation. Under these conditions, some salts present in the culture medium may also co-precipitate. Ultrasoundassisted extraction (UAE) and microwave-assisted extraction (MAE) have also been used to extract EPS, although to a lesser extent (Budarin et al. 2012). It is worth noting that ultrasound waves may also degrade EPS macromolecules (Du et al. 2012).

As yet, no study in the literature has evaluated the combined effect of nitrate $\left(\mathrm{NaNO}_{3}\right)$ starvation and PFD on the EPS production from $A$. platensis culture. Nitrogen starvation is known as a stress condition, which favors the accumulation of some reserve products and the production of EPS from cyanobacteria (Lupi et al. 1994). An increase in PFD has also been related to an increase in EPS yields (Markou et al. 2012). However, the intracellular events that lead to EPS production are still being deciphered. Some authors have proposed two events in diatoms: (1) the combined effect of PFD and nitrate starvation reduce cellular growth and cause an excess of assimilated carbon, which is released as carbohydrates; (2) the electrons accumulated in the photosynthetic electron transport chain induce the production of reactive oxygen species (ROS) that can cause cellular damage, thus EPS are produced to act as a protection barrier against these ROS (Miklestad 1995; Piedras et al. 2010).

In this work, an experimental design methodology was used to investigate the combined effect of nitrogen concentration and PFD on the biomass concentration and EPS content from the cultivation of $A$. platensis. The resulting products were analyzed as for their protein, carbohydrate and metals composition. Furthermore, EPS samples were characterized by infrared spectroscopy, and for their thermogravimetric and dynamic rheological properties.

\section{Materials and methods Microorganism}

Arthrospira platensis was provided by the Elizabeth Aidar microalgae collection from the Fluminense Federal University (Niterói, RJ/Brazil). The cell suspension of A. platensis was first cultivated in $300 \mathrm{~mL}$ modified Zarrouk's medium at $32{ }^{\circ} \mathrm{C}$, according to George (1976), to be used as an inoculum. The experiments were carried out at room temperature $\left(23^{\circ} \mathrm{C}\right)$ in Erlenmeyer flasks at a PFD of $150 \mu \mathrm{E} \mathrm{m}^{-2} \mathrm{~s}^{-1}$ and under 
constant stirring. All other reagents were purchased from Sigma Aldrich (São Paulo, SP, Brazil). Distilled and deionized water was used in all cases.

\section{Culture media}

Prior to experimental conditions, cultures were grown in 5-L bottles with $3700 \mathrm{~mL}$ of modified Zarrouk's medium (George 1976) and $300 \mathrm{~mL}$ of A. platensis inoculum, and incubated in a germination chamber at $(32 \pm 2)^{\circ} \mathrm{C}$ with constant aeration and white LED lighting at a PFD of $1000 \mu \mathrm{E} \mathrm{m} \mathrm{m}^{-2} \mathrm{~s}^{-1}$. Measurements of the PFD were carried out with a QSL 2100 dosimeter from Biospherical Instruments Inc. (San Diego, CA, USA). As LED lamps have unequal values of PFD depending on the region of the bottle surface, through which the light passes, a complete mapping of PFD values was made along 36 points on the surface of the bottle.

\section{Experimental design}

Using the Design Expert program, version 10.0.6.0., a 3-level factorial design $\left(3^{2}\right)$ was applied to plan culture conditions for the production of $A$. platensis biomass and EPS. A total of 12 runs were planned, nine of which for combinations of three levels and a central point in triplicate (Table 1). The independent variables were $\mathrm{NaNO}_{3}$ concentration $(0.5,1.125$, and $\left.2 \mathrm{~g} \mathrm{~L}^{-1}\right)$ and PFD $\left(200,600\right.$ and $1000 \mu \mathrm{E} \mathrm{m} \mathrm{m}^{-2} \mathrm{~s}^{-1}$. The two responses evaluated were biomass concentration $\left(\mathrm{mg} \mathrm{L}^{-1}\right)$ and EPS yield $\left(\mathrm{mg} \mathrm{g}^{-1}\right)$. The effect of each factor was determined by the analysis of variance (ANOVA) for a confidence level of $95 \%$.

\section{Monitoring of growth and determination of the final biomass concentration}

A. platensis growth was monitored by daily measurements of the optical density (O.D.) of the cellular suspension at $730 \mathrm{~nm}$ for 21 days. The specific growth rate $(\mu)$ was determined over the exponential growth phase, and given by Eq. 1:

$$
\mu=(\ln x 2-\ln x 1) /\left(t_{2}-t_{1}\right),
$$

where $x_{1}$ and $x_{2}$ are the biomass concentrations, and $t_{1}$ and $t_{2}$ are the times, corresponding to the beginning and the end of the exponential phase, respectively.

To determine the dry biomass weight, aliquots of $20 \mathrm{~mL}$ were taken from the culture medium at the end of each experiment and filtered through 0.7-1.2 $\mu \mathrm{m}$ Sartorius glass fiber membranes that had been previously weighed. After being extensively washed to eliminate excess of salt, the membranes were dried at $105{ }^{\circ} \mathrm{C}$ in an Ohaus ${ }^{\circledR}$ model MB45 Moisture Analyzer balance for approximately $15 \mathrm{~min}$, and weighed, giving the dry biomass $(g)$ by difference.

\section{EPS production}

To recover the EPS from the extracellular medium, the procedure reported by Parikh and Madamwar (2006) was followed. Briefly, the filtered culture medium, which still contained some biomass, was centrifuged at 13,000 rpm for $20 \mathrm{~min}$ in a Hettich Rotixa centrifuge, model 420R (Andreas Hettich $\mathrm{GmbH}$ \& Co. KG, Tuttlingen, Germany). The resulting supernatant was heated at $70{ }^{\circ} \mathrm{C}$ for $12 \mathrm{~h}$, reducing its volume to $1 / 4$. The EPS were then recovered by adding ice-cooled ethyl alcohol. After $12 \mathrm{~h}$ at $4{ }^{\circ} \mathrm{C}$, the product was filtered and completely dried in an oven at $60{ }^{\circ} \mathrm{C}$. To eliminate residual salt, the samples

Table 1 Experimental matrix for EPS production with the corresponding variables and responses

\begin{tabular}{|c|c|c|c|c|}
\hline \multirow[t]{2}{*}{ Experiment number } & \multicolumn{2}{|l|}{ Factors } & \multicolumn{2}{|l|}{ Response } \\
\hline & $\mathrm{A}-\mathrm{NaNO}_{3}\left(\mathrm{mg} \mathrm{L}^{-1}\right)$ & $B-P F D\left(\mu E m^{-2} s^{-1}\right)$ & Biomass $\left(\mathrm{g} \mathrm{L}^{-1}\right)$ & $\operatorname{EPS}\left(\mathrm{mg} \mathrm{g}^{-1}\right)$ \\
\hline 1 & 0.25 & 200 & 0.78 & 111 \\
\hline 2 & 1.125 & 200 & 0.642 & 70 \\
\hline 3 & 2 & 200 & 0.767 & 100 \\
\hline 4 & 0.25 & 600 & 0.868 & 47 \\
\hline 5 & 1.125 & 600 & 1.07 & 50 \\
\hline 6 & 2 & 600 & 1.292 & 46 \\
\hline 7 & 0.25 & 1000 & 0.871 & 40 \\
\hline 8 & 1.125 & 1000 & 0.94 & 47 \\
\hline 9 & 2 & 1000 & 0.913 & 100 \\
\hline 10 & 1.125 & 600 & 1.073 & 54 \\
\hline 11 & 1.125 & 600 & 1.062 & 51 \\
\hline 12 & 1.125 & 600 & 1.087 & 45 \\
\hline
\end{tabular}


were resolubilized in distilled water and then dialyzed against water under constant stirring at room temperature for $24 \mathrm{~h}$. The final product was recovered by adding 95\% ethyl alcohol and lyophilized.

\section{Chemical and physicochemical characterization of EPS}

The methodology proposed by Dubois et al. (1956) was used to quantify the total carbohydrate content for each recovered EPS sample, by adding $\mathrm{H}_{2} \mathrm{SO}_{4}$ concentrated at $80 \%(\mathrm{~m} / \mathrm{v})$ and phenol at $5 \%(\mathrm{v} / \mathrm{v})$. A standard curve was obtained using D-glucose.

Soluble protein was determined by the Folin's method, using bovine serum albumin as the standard (Lowry et al. 1951).

Fourier transform infrared spectroscopy (FTIR) analyses were carried out using a Perkin Elmer spectrometer, Frontier model (Waltham, MA, USA) at room temperature, using $\mathrm{KBr}$ disks, in the $4000-400 \mathrm{~cm}^{-1}$ range, with accumulation of 20 scans and $4 \mathrm{~cm}^{-1}$ resolution.

Thermogravimetric analyses were carried out for EPS samples under nitrogen atmosphere on a TGA Q-500 equipment from TA Instruments (New Castle, DE, USA). Approximately, $10 \mathrm{mg}$ of sample were heated from 20 to $700{ }^{\circ} \mathrm{C}$, at a $10^{\circ} \mathrm{C} / \mathrm{min}$ rate.

The rheological properties of selected EPS samples were investigated at $5 \mathrm{~g} \mathrm{~L}^{-1}$ and $10 \mathrm{~g} \mathrm{~L}^{-1}$ at $25{ }^{\circ} \mathrm{C}$ with an AR G2 controlled stress rheometer (TA Instruments Inc.), equipped with a coaxial cylinder geometry. Initially, strain sweep tests were conducted as the variation of complex modulus at $6.28 \mathrm{rad} / \mathrm{s}$ to determine the linear viscoelastic range. After a period of $10 \mathrm{~min}$, an oscillatory frequency scan was performed, from $10^{-1}$ to $7 \times 10^{2} \mathrm{rad} \mathrm{s}^{-1}$ (with a deformation value of $10 \%$ ), within the region of linear viscoelasticity. Finally, viscosity changes under steady-flow regime were investigated as a function of shear rate, from 10 to $10^{2} \mathrm{~s}^{-1}$.

\section{Statistical analysis}

The carbohydrate and protein quantifications were carried out in triplicate and the results were expressed as mean values \pm standard deviation (SD). One-way ANOVA was applied to the data by using the PAST 3.20 software, available at https://folk.uio.no/ohammer/past. The mean values were compared by the Tukey's test considering a confidence level of $95 \%$ and level of significance $(p<0.05)$.

\section{Results and discussion}

Evaluation of Arthrospira platensis growth under different cultivation conditions

The growth curves of $A$. platensis cultivated in different culture conditions are presented in Fig. 1. As observed, none of the conditions presented an adaptation

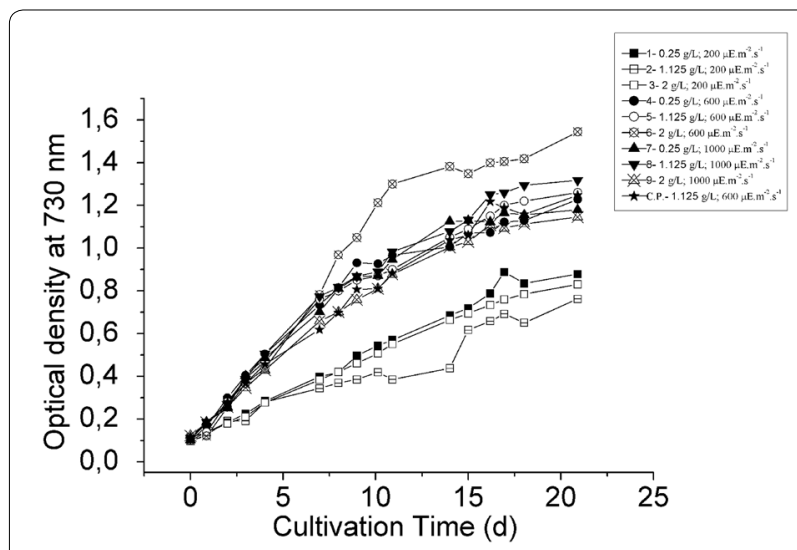

Fig. 1 Growth curves of A. platensis at different conditions of $\mathrm{NaNO}_{3}$ and PFD. (C. P. refers to central point)

phase. Condition 6 resulted in the highest growth rate $(\mu=0.55)$, in medium with $2 \mathrm{~g} \mathrm{~L}^{-1}$ of $\mathrm{NaNO}_{3}$ and under $600 \mu \mathrm{E} \mathrm{m} \mathrm{m}^{-2} \mathrm{~s}^{-1}$ of PFD. Condition 2 led to the lowest growth rate, with $1.125 \mathrm{~g} \mathrm{~L}^{-1}$ of $\mathrm{NaNO}_{3}$ and a PFD of $200 \mu \mathrm{E} \mathrm{m}^{-2} \mathrm{~s}^{-1}$, followed closely by number $1\left(0.25 \mathrm{~g} \mathrm{~L}^{-1}\right.$ of $\mathrm{NaNO}_{3}$ and $200 \mu \mathrm{E} \mathrm{m} \mathrm{m}^{-2} \mathrm{~s}^{-1}$ of PFD) and condition 3 $\left(2 \mathrm{~g} \mathrm{~L}^{-1}\right.$ of $\mathrm{NaNO}_{3}$ and $200 \mu \mathrm{E} \mathrm{m}^{-2} \mathrm{~s}^{-1}$ of PFD). All three of these conditions corresponded to the lowest PFD used. The results demonstrate that the $A$. platensis growth rate was practically independent of the $\mathrm{NaNO}_{3}$ concentration, and indicates that the PFD was the limiting factor.

The PFD values may have affected the growth rate, which increased until reaching a point of light saturation and, from this point, there may even have been a decrease in the rate of growth as a consequence of photo inhibition (Carvalho et al. 2011). In cultures grown at $1000 \mu \mathrm{E} \mathrm{m}{ }^{-2} \mathrm{~s}^{-1}$ and with $\mathrm{NaNO}_{3}$ at a concentration of $2 \mathrm{~g} \mathrm{~L}^{-1}$, light saturation may have occurred, which resulted in a lower rate of cell growth. In cultures using a PFD at $600 \mu \mathrm{E} \mathrm{m}^{-2} \mathrm{~s}^{-1}$, the $\mathrm{NaNO}_{3}$ concentration was probably the limiting factor for $A$. platensis growth.

\section{Final biomass concentration and EPS yield under different growth conditions}

Some researchers reported that different concentrations of $\mathrm{NaNO}_{3}$ and PFD could induce the EPS production from cyanobacteria (Aikawa et al. 2012; Dejsungkranont et al. 2017; Ohki et al. 2014; Villay et al. 2013). Modified Zarrouk's medium has $2.5 \mathrm{~g} \mathrm{~L}^{-1}$ of $\mathrm{NaNO}_{3}$. Therefore, for the experimental design, a $\mathrm{NaNO}_{3}$ concentration $\left(2 \mathrm{~g} \mathrm{~L}^{-1}\right)$ close to that for which regular cell growth is already known and a concentration reduced by $75 \%$ $\left(0.5 \mathrm{~g} \mathrm{~L}^{-1}\right)$ were used. For the PFD, the minimum and maximum values that have reportedly been used for $A$. 
platensis are $57.2 \mu \mathrm{E} \mathrm{m}^{-2} \mathrm{~s}^{-1}$ (Chentir et al. 2018), and $700 \mu \mathrm{E} \mathrm{m}^{-2} \mathrm{~s}^{-1}$ (Aikawa et al. 2012), respectively.

The values of the final biomass concentration and the EPS yield are given in Table 1. In general, the O.D. values were related to the biomass concentration. However, there was some variation for the intermediate values, although the differences between the expected O.D. and the observed O.D. were not so high, suggesting they could have been caused by small measurements error.

Considering the results, the highest final biomass concentration $\left(1.292 \mathrm{~g} \mathrm{~L}^{-1}\right)$ was observed under conditions with the highest $\mathrm{NaNO}_{3}$ concentration $\left(2 \mathrm{~g} \mathrm{~L}^{-1}\right)$. However, for the EPS yield, the best conditions were achieved under the lowest $\mathrm{NaNO}_{3}\left(0.25 \mathrm{~g} \mathrm{~L}^{-1}\right)$ and PFD $\left(200 \mu \mathrm{E} \mathrm{m}^{-2} \mathrm{~s}^{-1}\right)$, which generated $111 \mathrm{mg} \mathrm{g}^{-1}$ of EPS. The second highest EPS content $\left(100 \mathrm{mg} \mathrm{g}^{-1}\right)$ was obtained under conditions of the highest values of $\mathrm{NaNO}_{3}\left(2 \mathrm{~g} \mathrm{~L}^{-1}\right)$ and PFD $\left(1000 \mu \mathrm{E} \mathrm{m} \mathrm{m}^{-2} \mathrm{~s}^{-1}\right)$. In other words, the maximum EPS content (EPS mass/biomass) was attained using both extremes of the experimental design.

The results presented in Fig. 2a, b show that the EPS production by $A$. platensis was not directly associated to its growth. As can be observed, the response in which the highest final biomass concentration was obtained differed from that which generated the highest EPS production. In general, metabolic stress may negatively affect cyanobacteria growth, during which cells use their energy to produce reserve compounds such as carbohydrates and EPS (Santos et al. 2019). Condition 9 was an exception, since this condition promoted one of the highest EPS yields and, at the same time, one of the highest final biomass concentrations.

Table 2 shows the results of the coefficients and their interactions, $\mathrm{R}^{2}$, lack of fit and the $p$-values for final biomass concentration and EPS yield from A. platensis. A 95\% confidence level was adopted $(p<0.05)$. The model was significant for final biomass concentration with a $p$ value equal to 0.0379 . It was found that the PFD and its interactions have a significant influence on the model. For the EPS production, the model was significant, with a $p$-value equal to 0.0164 , and the variables that showed a significant influence were the PFD and its interactions.

The regression equation was generated, as shown in Eqs. 2, 3, according to the values presented in Table 2:

$$
\begin{aligned}
& \text { Biomass concentration } \\
& \begin{aligned}
=1.07 & +0.0755 A+0.0892 B \\
+ & 0.0138 \mathrm{AB}+0.0244 A^{2}-0.2646 B^{2}, \\
\text { EPS yield }= & 44.54+8 A-15.67 B+17.75 \mathrm{AB} \\
& +12.88 A^{2}+24.88 B^{2} .
\end{aligned}
\end{aligned}
$$

It is noteworthy that the lack of fit values for both biomass and EPS production were significant $(p<0.05)$. In this case, the model does not have a good predictive capacity. Despite the lack of adjustment, it is possible to visualize the best working regions.

In Fig. 2a, the response surface graphics show that the conditions which led to the highest final biomass concentration were a PFD of $600 \mu \mathrm{E} \mathrm{m}^{-2} \mathrm{~s}^{-1}$ and $2 \mathrm{~g} \mathrm{~L}^{-1} \mathrm{NaNO}_{3}$. A decrease in biomass production was also observed when the value of PFD was smaller. The PFD can influence cyanobacteria photosynthesis. Excessive or insufficient light may affect the biomass productivity and yield of metabolic products (Carvalho et al. 2011). It is likely that the nitrogen-reduced conditions in this work did not compromise the biomass production and were high enough to sustain the cell growth. However, the lowest PFD negatively affected the biomass production. In this case, it seems that light intensity was insufficient to support the biomass production. Aikawa et al. (2012) also observed that biomass production was related to the PFD, and that $A$. platensis produced the highest final biomass concentration $\left(1.6 \mathrm{~g} \mathrm{~L}^{-1}\right)$ at $700 \mu \mathrm{E} \mathrm{m}^{-2} \mathrm{~s}^{-1}$, the highest PFD value they tested. Under the smallest PFD value, $20 \mu \mathrm{E} \mathrm{m} \mathrm{m}^{-2} \mathrm{~s}^{-1}$, a much smaller final biomass concentration $\left(0.1 \mathrm{~g} \mathrm{~L}^{-1}\right)$ was attained.

Figure $2 b$ shows the response surface obtained for the EPS content $\left(\mathrm{mg} \mathrm{g}^{-1}\right)$. The highest values were observed at the two extremes, 111 and $100 \mathrm{mg} \mathrm{g}^{-1}$, using conditions 1 and 9, respectively, in addition to condition 3, which also generated an EPS yield of $100 \mathrm{mg} \mathrm{g}^{-1}$. The EPS production from $A$. platensis was also affected by the PFD; however, it was not the only determinant variable. $\mathrm{NaNO}_{3}$ starvation contributes to the increase in the $\mathrm{C} / \mathrm{N}$ ratio. Consequently, it promotes the incorporation of carbon reserve in the EPS (Otero and Vincenzini 2003). The lowest PFD $\left(200 \mu \mathrm{E} \mathrm{m}^{-2} \mathrm{~s}^{-1}\right)$ and $\mathrm{NaNO}_{3}$ concentration $\left(0.5 \mathrm{~g} \mathrm{~L}^{-1}\right)$ resulted in the highest EPS yield. It is possible that the combined effects led to cells producing more EPS in response to the limited conditions. This result is in accordance with that found by Chentir et al. (2018), who obtained the highest EPS yield, $0.902 \mathrm{~g} \mathrm{~g}^{-1}$, using $0.5 \mathrm{~g} \mathrm{~L}^{-1} \mathrm{NaNO}_{3}$ combined with a PFD of $57.2 \mu \mathrm{E} \mathrm{m}^{-2} \mathrm{~s}^{-1}$ in A. platensis.

Chentir et al. (2017) evaluated the maximization of EPS production from $A$. platensis as a function of variations in $\mathrm{NaCl}$ concentration and PFD. Although the PFD did not have any positive effect on EPS production, its interaction with the $\mathrm{NaCl}$ concentration provided a $0.98 \mathrm{~g} \mathrm{~g}^{-1}$ yield of EPS. On the other hand, Dejsungkranont et al. (2017), through studying the effect of PFD on the production of EPS from $A$. platensis, observed that the highest level of PFD $\left(203 \mu \mathrm{E} \mathrm{m}^{-2} \mathrm{~s}^{-1}\right)$ favored EPS production 
Design-Expert ${ }^{ø}$ Software

Trial Version

Factor Coding: Actual

Biomass ( $\mathrm{g} / \mathrm{L}$ )

Design Points:

Above Surface

Below Surface

$0,6 4 \longdiv { \square } 1,292$

$\mathrm{X} 1=\mathrm{A}$
$\mathrm{X} 2=\mathrm{B}$

a

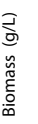

Factor Coding: Actual

EPS (mg/g)

Design Points:

Above Surface

Below Surface

$40 \lcm{\square} \square$

$\mathrm{X} 1=\mathrm{A}$

$\mathrm{X} 2=\mathrm{B}$
3D Surface

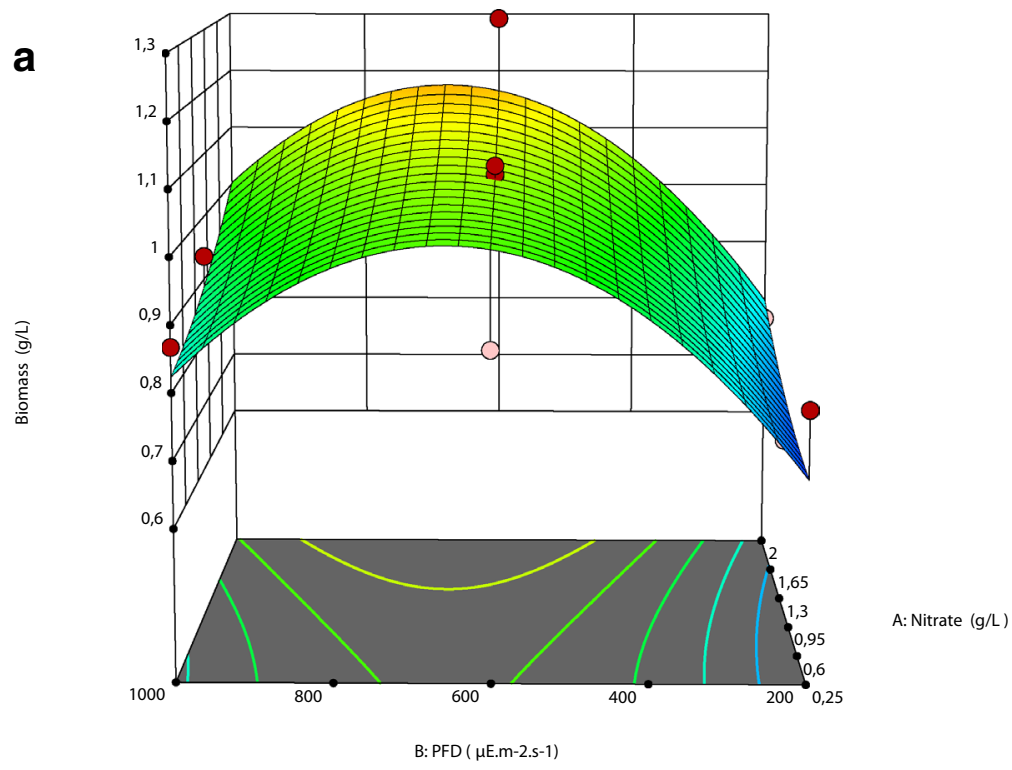

B: PFD ( $\mu$ E.m-2.s-1)

\section{D Surface}

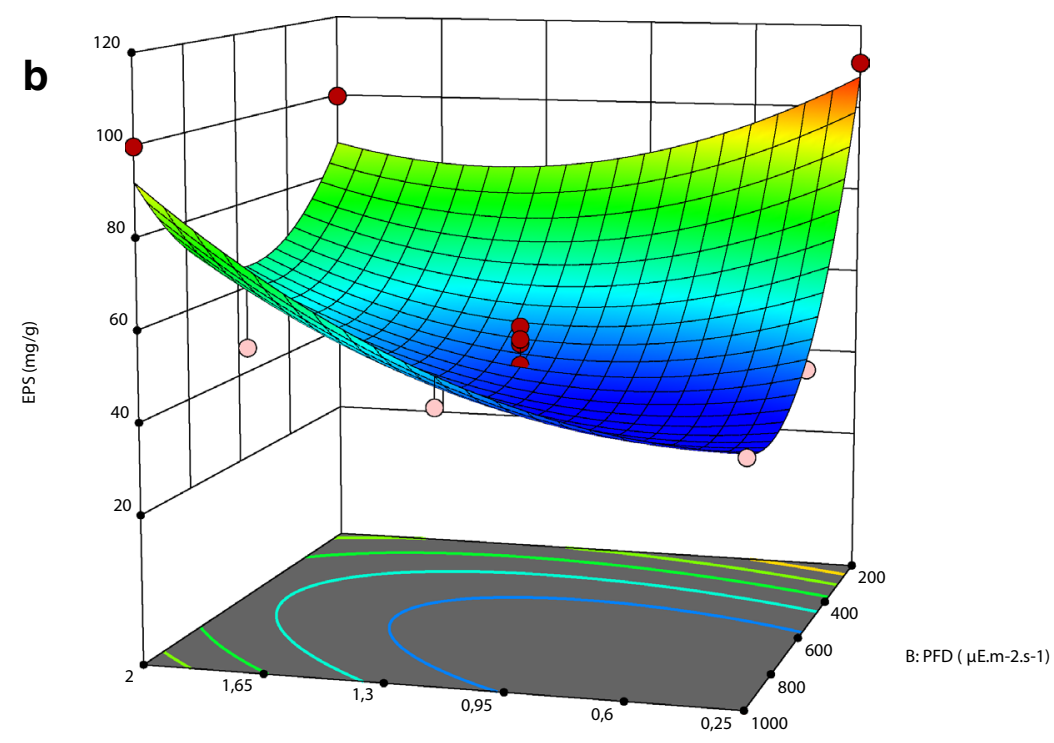

A: Nitrate $(g / L)$

A: Nitrate $(g / L)$

$x 2$ 
Table $2 R^{2}$, lack of fit, $p$-value, coefficients and effects on quadratic model to responses obtained of biomass and EPS

\begin{tabular}{lccccc}
\hline Source & \multicolumn{2}{l}{ Biomass yield } & & EPS \\
\cline { 2 - 3 } & Coefficient & $\boldsymbol{p}$-value & & Coefficient & $\boldsymbol{p}$-value \\
\hline Model & & 0.0379 & & 0.0164 \\
$\mathrm{~A}-\mathrm{NaNO}_{3}$ & 0.0755 & 0.1325 & & 0.1846 \\
$\mathrm{~B}-\mathrm{PFD}$ & 0.0892 & 0.0856 & -15.67 & 0.0261 \\
$\mathrm{NaNO}_{3} \times \mathrm{PFD}$ & 0.0138 & 0.8045 & & 17.75 & 0.0349 \\
$\mathrm{NaNO}_{3} \times \mathrm{NaNO}_{3}$ & 0.0244 & 0.7209 & & 12.88 & 0.1590 \\
$\mathrm{PFD} \times \mathrm{PFD}$ & -0.2646 & 0.0066 & & 24.88 & 0.0209 \\
$R^{2}$ & 0.8060 & & 0.8563 & \\
Lack of fit & 0.0006 & & 0.0139 & \\
\hline
\end{tabular}

$\left(956.4 \pm 37.3 \mathrm{mg} \mathrm{L}^{-1}\right)$ as well as biomass $\left(1.5 \mathrm{~g} \mathrm{~L}^{-1}\right)$; whereas under the lowest PFD $\left(101 \mu \mathrm{E} \mathrm{m}^{-2} \mathrm{~s}^{-1}\right), 0.8 \mathrm{~g} \mathrm{~L}^{-1}$ of biomass and $637.3 \pm 41.3 \mathrm{mg} \mathrm{L}^{-1}$ of EPS were obtained.

Trabelsi et al. (2009a) carried out a study evaluating the effect of different temperatures and PFD on the final biomass and EPS concentrations by $A$. platensis, and described a possible correlation between the two responses. According to the authors, the production of biomass and EPS are mutually dependent, and the increase of EPS production may be associated with the kinetics of growth. To achieve a greater EPS content, it is necessary to optimize the PFD while the temperature should be maintained between 30 and $35{ }^{\circ} \mathrm{C}$. In that work, $A$. platensis produced the maximum EPS content at the highest PFD used, $180 \mu \mathrm{E} \mathrm{m}^{-2} \mathrm{~s}^{-1}$, with $297.4 \pm 11.1 \mathrm{mg} \mathrm{L}^{-1}$. The result for EPS content found by Trabelsi et al. (2009a), $210 \mathrm{mg} \mathrm{L}^{-1}$, under $100 \mu \mathrm{E} \mathrm{m}^{-2} \mathrm{~s}^{-1}$ and $2.5 \mathrm{~g} \mathrm{~L}^{-1} \mathrm{NaNO}_{3}$, was twice that of our result, $91 \mathrm{mg} \mathrm{L}^{-1}$.

The results found in the present study demonstrate that the choice of the best culture conditions depended on the response of interest. The results in Fig. 2a, b showed that the production of EPS by A. platensis was not directly associated to growth. Nevertheless, it is possible to choose a condition in which the EPS content as well as biomass concentration could be produced at reasonable values.

Other studies in the literature using different microorganisms have reported the effect of culture conditions on the EPS content and biomass concentration. For Cyanothece sp. 113, $\mathrm{NaNO}_{3}$ concentrations between 0 and $200 \mathrm{mg} \mathrm{L}^{-1}$ were used (Su et al. 2007). In this case, the final biomass concentration was observed to increase, reaching $1.2 \mathrm{~g} \mathrm{~L}^{-1}$ with a $\mathrm{NaNO}_{3}$ concentration of $74.3 \mathrm{mg} \mathrm{L}^{-1}$, but then decreased at values higher than $100 \mathrm{mg} \mathrm{L}^{-1}$. However, a decrease in EPS concentration,

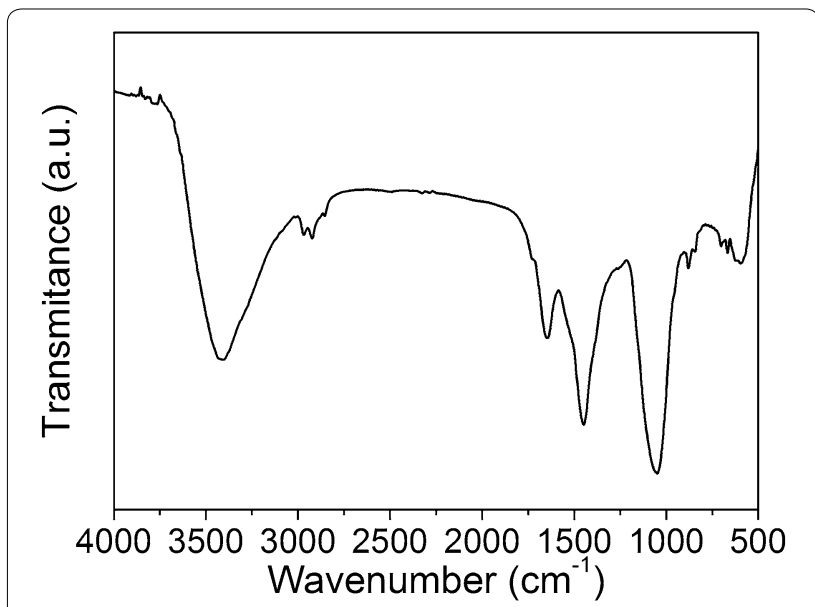

Fig. 3 Characteristic FTIR spectrum for EPS from A. platensis

from $7 \mathrm{~g} \mathrm{~L}^{-1}$ to $5 \mathrm{~g} \mathrm{~L}^{-1}$, was reported elsewhere when $200 \mathrm{mg} \mathrm{L}^{-1}$ of $\mathrm{NaNO}_{3}$ was used. In the same work, the PFD effect was evaluated in the $20-100 \mu \mathrm{E} \mathrm{m}^{-2} \mathrm{~s}^{-1}$ range and the best condition was found to be $86 \mu \mathrm{E} \mathrm{m}^{-2} \mathrm{~s}^{-1}$ for both biomass and EPS production (Su et al. 2007).

\section{FTIR analyses}

Figure 3 shows the FTIR spectrum for EPS samples from $A$. platensis. The broad bands observed around $3400 \mathrm{~cm}^{-1}$ are attributed to $\mathrm{O}-\mathrm{H}$ and $\mathrm{N}-\mathrm{H}$ stretching. The weak absorptions in the region $3000 \mathrm{~cm}^{-1}$ to $2840 \mathrm{~cm}^{-1}$ are associated to $\mathrm{C}-\mathrm{H}$ asymmetrical and symmetrical stretching modes of methyl and methylene groups. The absorption at $1650 \mathrm{~cm}^{-1}$ is attributed to $\mathrm{C}=\mathrm{O}$ stretching of carboxylate and amide groups (amide I band). The high-intensity band with maximum at $1442 \mathrm{~cm}^{-1}$ is attributed to more complex vibrations, associated to $\mathrm{O}-\mathrm{H}$ bending (Can et al. 2019; Trabelsi et al. 2009a). The most intense absorption of the spectrum, at $1046 \mathrm{~cm}^{-1}$, may be attributed to $\mathrm{C}-\mathrm{O}-\mathrm{C}, \mathrm{S}-\mathrm{O}$ and $\mathrm{P}-\mathrm{O}-\mathrm{C}$ stretching vibrations. This result evidenced the presence of polysaccharides, proteins/polypeptides, and of sulfate and phosphate groups linked to polymeric substances.

\section{Thermal analysis}

Thermogravimetric analysis is an important technique, as it demonstrates the thermal stability of the EPS (Fig. 4). The EPS displayed two stages of thermal degradation. In the first stage, up to $150{ }^{\circ} \mathrm{C}, 10 \%$ weight was lost and this may be attributed to the loss of water and other volatile substances. In the second stage, the degradation of the polymer chain occurred, between 225 and $350{ }^{\circ} \mathrm{C}$, with $50 \%$ of the total mass lost. 


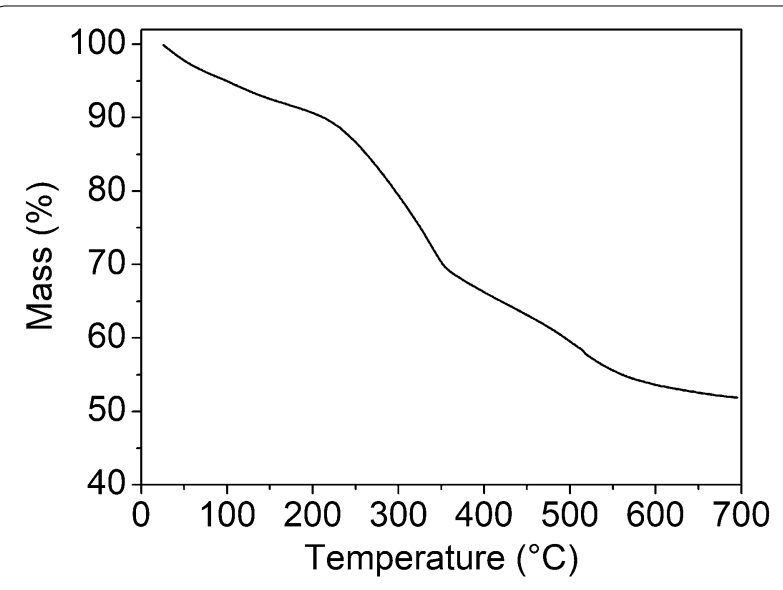

Fig. 4 Thermogram for EPS obtained from A. platensis

The thermal degradation of EPS from microalgae and cyanobacterium was recently reported. Two stages were observed for the EPS from Dunaliella salina; in the first, $15 \%$ weight was lost at up to $150^{\circ} \mathrm{C}$. In the second, $55 \%$ of total EPS weight loss was observed with maximum loss at $240{ }^{\circ} \mathrm{C}$ (Mishra et al. 2011). On the other hand, for the EPS from Nostoc carneum, three stages of thermal degradation were detected. In the first stage, 15\% weight was lost up to $155^{\circ} \mathrm{C}$. In the second stage, with a maximum at $237{ }^{\circ} \mathrm{C}, 39 \%$ weight was lost, attributed to polysaccharide degradation. The third phase occurred up to $378{ }^{\circ} \mathrm{C}$ with $32 \%$ of weight loss (Hussein et al. 2015).

\section{Carbohydrate and protein quantification}

The chemical composition of the EPS depends on environmental conditions and the microorganism studied (Nouha et al. 2018). According to Wingender et al. (1999), the majority of EPS constituents are carbohydrates and proteins. In $A$. platensis, the carbohydrate and protein content were estimated as $55 \%$ and $13 \%$, respectively, in a photoautotrophic growth for 25 days (Pignolet et al. 2013). Carbohydrate and protein contents for A. platensis EPS determined in the present work are shown in Table 3. The highest contents of carbohydrates, $39.5 \pm 2.34 \mathrm{mg} \mathrm{g}^{-1}$ and $38.73 \pm 2.55 \mathrm{mg} \mathrm{g}^{-1}$, were observed under conditions $5\left(1.125 \mathrm{gL}^{-1} \mathrm{NaNO}_{3}\right.$ and $\left.600 \mu \mathrm{E} \mathrm{m} \mathrm{m}^{-2} \mathrm{~s}^{-1}\right)$ and 9 $\left(2 \mathrm{gL}^{-1} \mathrm{NaNO}_{3}\right.$ and $\left.1000 \mu \mathrm{E} \mathrm{m}^{-2} \mathrm{~s}^{-1}\right)$, respectively.

According to Depraetere et al. (2015), when the nitrate source is depleted, protein synthesis is reduced. In the present work, the highest protein concentrations, $7.05 \pm 0.30 \mathrm{mg} \mathrm{g}^{-1}$ and $6.46 \pm 0.20 \mathrm{mg} \mathrm{g}^{-1}$, were observed for intermediate $\mathrm{NaNO}_{3}$ concentrations, under conditions $5\left(1.125 \mathrm{gL}^{-1}\right.$ of $\mathrm{NaNO}_{3}$ and $\left.600 \mu \mathrm{E} \mathrm{m}^{-2} \mathrm{~s}^{-1}\right)$ and 8 $\left(1.125 \mathrm{gL}^{-1}\right.$ of $\mathrm{NaNO}_{3}$ and $\left.1000 \mu \mathrm{E} \mathrm{m}^{-2} \mathrm{~s}^{-1}\right)$, respectively.

\section{Rheological properties}

Aqueous solutions of EPS $01\left(0.25 \mathrm{gL}^{-1} \mathrm{NaNO}_{3}\right.$ and $\left.200 \mu \mathrm{E} \mathrm{m}^{-2} \mathrm{~s}^{-1}\right)$ and EPS $09\left(2 \mathrm{gL}^{-1} \mathrm{NaNO}_{3}\right.$ and $1000 \mu \mathrm{E} \mathrm{m}^{-2} \mathrm{~s}^{-1}$ ) were prepared at $5 \mathrm{~g} \mathrm{~L}^{-1}$ and $10 \mathrm{~g} \mathrm{~L}^{-1}$, and their rheological properties were investigated. Figure $5 \mathrm{a}$, b shows the variation of storage modulus, $G^{\prime}$, and loss modulus, $G^{\prime \prime}$, with the oscillatory frequency. Their rheological behaviors were quite similar to that previously observed for other polysaccharides, such as gum algaroba, a galactomannan extracted from Prosopis juliflora (Azero and Andrade 2006). At very low frequencies, the viscous character predominated. After the crossing of $G^{\prime}$ with $G^{\prime \prime}$, the elastic character was predominant. As expected, the value of the frequency at which the crossing occurs was smaller for the highest concentration. The same behavior was observed for the EPS09 supernatant at 5 and $10 \mathrm{~g} \mathrm{~L}^{-1}$.

Our results differ from those reported by Chentir et al. (2017), who also assessed the EPS of A. platensis. The authors described a gel-like behavior, in which the

Table 3 Carbohydrates and proteins in different culture conditions

\begin{tabular}{|c|c|c|c|c|}
\hline \multirow[t]{2}{*}{ Experiment number } & \multicolumn{2}{|l|}{ Factors } & \multicolumn{2}{|l|}{ Response } \\
\hline & $\mathrm{A}-\mathrm{NaNO}_{3}\left(\mathrm{mg} \mathrm{L}^{-1}\right)$ & $B-P F D\left(\mu E m^{-2} s^{-1}\right)$ & Carbohydrates $\left(\mathrm{mg} \mathrm{g}^{-1}\right)$ & Proteins $\left(\mathrm{mg} \mathrm{g}^{-1}\right)$ \\
\hline 1 & 0.25 & 200 & $23 \pm 2.27^{a}$ & $4.67 \pm 0.28^{a}$ \\
\hline 2 & 1.125 & 200 & $23.5 \pm 1.19^{a}$ & $4.2 \pm 1.37 a, b, c$ \\
\hline 3 & 2 & 200 & $24.43 \pm 1.40^{a}$ & $5.46 \pm 0.40^{a}$ \\
\hline 4 & 0.25 & 600 & $27.43 \pm 0.37^{b}$ & $3.49 \pm 0.10^{b}$ \\
\hline 5 & 1.125 & 600 & $39.5 \pm 2.34^{\mathrm{e}}$ & $7.05 \pm 0.30^{\mathrm{e}}$ \\
\hline 6 & 2 & 600 & $17.53 \pm 0.5^{c}$ & $3.14 \pm 0.24^{b}$ \\
\hline 7 & 0.25 & 1000 & $23.67 \pm 1.41^{\mathrm{a}}$ & $2.56 \pm 0.07^{d}$ \\
\hline 8 & 1.125 & 1000 & $34 \pm 1.49^{d}$ & $6.46 \pm 0.20^{e}$ \\
\hline 9 & 2 & 1000 & $38.73 \pm 2.55^{\mathrm{e}}$ & $4.80 \pm 0.38^{a}$ \\
\hline 10 (central point) & 1.125 & 600 & $36.63 \pm 0.51^{\mathrm{e}}$ & $4.18 \pm 0.19^{c}$ \\
\hline
\end{tabular}

Statistical differences (One-way ANOVA followed by Tukey's test; $p<0.05$ ) among conditions are represented as different letters 

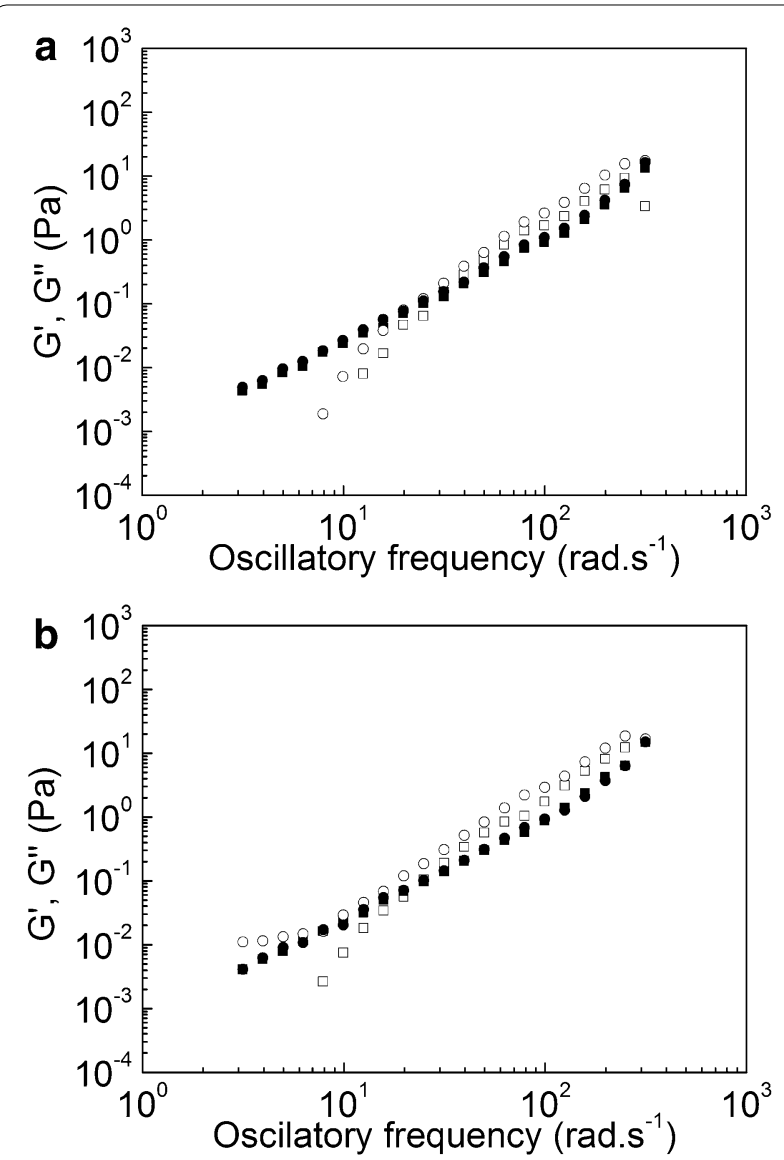

Fig. 5 Variation of storage and loss modulus values with oscillatory frequency for the solutions at $5 \mathrm{gL}^{-1}(\mathbf{a})$ and $10 \mathrm{gL}^{-1}(\mathbf{b})$

storage modulus values were higher than the loss modulus values at different concentrations (1\%, 2.5\% and 5\%). Furthermore, Mouhim et al. (1993) found a non-Newtonian character for EPS dispersions of Spirulina platensis, which was attributed to its polyanionic nature.

\section{Conclusions}

The present work demonstrated that combined values of $\mathrm{NaNO}_{3}$ and PFD were capable of enhancing the EPS yield and biomass concentration of Arthrospira platensis. The EPS production was not associated with the growth rate, and under nitrate starvation and the lowest PFD, the highest EPS production was achieved. The FTIR spectra showed that the EPS contained sulfate groups, carbohydrate and proteins, while the rheological studies suggested that the EPS exhibited a dilute solution behavior. In terms of further enhancing the biomass concentration and EPS yield of A. platensis, whilst also reducing production costs, alternative culture media could next be evaluated.

\section{Abbreviations}

EPS: Extracellular polymeric substances; $\mathrm{NaCl}$ : Sodium chloride; $\mathrm{NaNO}_{3}$ : Sodium nitrate; PFD: Photon flux density; ANOVA: Analysis of variance; FTIR: Fourier transform infrared spectroscopy; TGA: Thermogravimetric analyses.

\section{Acknowledgements}

The authors thank Conselho Nacional de Desenvolvimento Científico e Tecnológico (CNPq) and Coordenação de Aperfeiçoamento de Pessoal de Nível Superior-Brasil (CAPES) for financial support.

\section{Authors' contributions}

MBFS contributed to the conceptualization, methodology, validation, formal analysis, investigation, data curation, writing —original draft, visualization; EGAR contributed to methodology, validation, formal analysis and investigation of rheological experiments; CMLLT contributed to the conceptualization, methodology, analysis, writing — review and editing, supervision, project administration, funding acquisition; CTA contributed to the analysis, writingreview and editing, supervision, project administration, funding acquisition. All authors read and approved the final manuscript.

\section{Funding}

This work was funded by Conselho Nacional de Desenvolvimento Científico e Tecnológico (CNPq) and Coordenação de Aperfeiçoamento de Pessoal de Nível Superior-Brasil (CAPES), Finance Code 001.

\section{Availability of data and materials}

The datasets used and/or analyzed during the current study are available from the corresponding author on reasonable request.

\section{Ethics approval and consent to participate}

Not applicable.

\section{Consent for publication \\ Not applicable.}

\section{Competing interests}

No potential conflicts of interest were disclosed.

\section{Author details}

${ }^{1}$ Programa de Pós-Graduação em Ciência de Alimentos, Instituto de Química, Universidade Federal do Rio de Janeiro, Avenida Athos da Silveira Ramos 149, Rio de Janeiro, RJ 21941-909, Brazil. ${ }^{2}$ Departamento de Ciências Naturais, Universidade Federal do Estado do Rio de Janeiro, Avenida Pasteur 458, Rio de Janeiro, RJ 22290-240, Brazil. ${ }^{3}$ Laboratório de Biotecnologia de Microalgas, Instituto Nacional de Tecnologia, Avenida Venezuela 82, Rio de Janeiro, RJ 20081-312, Brazil. ${ }^{4}$ Instituto de Macromoléculas Professora Eloisa Mano, Universidade Federal do Rio de Janeiro, Avenida Horácio Macedo 2030, Rio de Janeiro, RJ 21941-598, Brazil.

Received: 4 April 2020 Accepted: 7 August 2020

Published online: 16 August 2020

\section{References}

Ahmed M, Poortvliet TCWM, Wijnholds A, Staland LJ, Hasnain S (2014) Isolation, characterization and localization of extracellular polymeric substances from the cyanobacterium Arthrospira platensis strain MMG-9. Eur J Phycol 49:143-150. https://doi.org/10.1080/09670262.2014.895048

Aikawa S, Izumi Y, Matsuda F, Hasunuma T, Chang JS, Kondo A (2012) Synergistic enhancement of glycogen production in Arthrospira platensis by optimization of light intensity and nitrate supply. Bioresour Technol 108:211-215. https://doi.org/10.1016/j.biortech.2012.01.004

Arad S, Levy-Ontman O (2010) Red microalgae cell-wall polysaccharides: biotechnological aspects. Curr Opin Biotechnol 21:358-364. https://doi. org/10.1016/j.copbio.2010.02.008

Azero EG, Andrade CT (2006) Characterization of Prosopis juliflora seed gum and the effect of its addition to k-carrageenan systems. J Braz Chem Soc 17:844-850. https://doi.org/10.1590/S0103-50532006000500005

Baldev E, MubarakAli D, Shriraman, R, Pandiaraj D, Alharbi NS, Thajuddin N (2015) Extraction and partial characterization of exopolysaccharidesfrom 
marine cyanobacteria and their flocculation property. Res J Environ Sci 9(1):28-38. https://doi.org/10.3923/rjes.2015.28.38

Budarin V, Ross AB, Biller P, Riley R, Clark JH, Jones JM, Gilmour DJ, Zimmerman W (2012) Microalgae biorefinery concept based on hydrothermal microwave pyrolysis. Green Chem 14:3251-3254. https://doi.org/10.1039/ C2GC36202C

Can HK, Gurbuz F, Odabas M (2019) Partial characterization of cyanobacterial extracellular polymeric substances for aquatic ecosystems. Aquat Ecol 53:431-440. https://doi.org/10.1007/s10452-019-09699-z

Carvalho AP, Silva SO, Baptista JM, Malcata FX (2011) Light requirements in microalgal photobioreactors: an overview of biophotonic aspects. Appl Microbiol Biotechnol 89:1275-1288. https://doi.org/10.1007/s0025 3-010-3047-8

Challouf R, Trabelsi L, Dhieb BR, El Abed O, Yahia A, Ghozzi K, Ammar JB, Omran H, Ouada BH (2011) Evaluation of cytotoxicity and biological activities in extracellular polysaccharides released by Cyanobacterium Arthrospira platensis. Braz Arch Biol Technol 54:831-838. https://doi.org/10.1590/ S1516-89132011000400024

Chentir I, Hamdi M, Doumandji A, HadjSadok A, Ouada HB, Nasri M, Jridi M (2017) Enhancement of extracellular polymeric substances (EPS) production in Spirulina (Arthrospira sp.) by two-step cultivation process and partial characterization of their polysaccharidic moiety. Int J Biol Macromol 105:1412-1420. https://doi.org/10.1016/j.ijbiomac.2017.07.009

Chentir I, Doumandji A, Ammar J, Zili F, Jridi M, Markou G, Ouada HB (2018) Induced change in Arthrospira sp. (Spirulina) intracellular and extracellular metabolites using multifactor stress combination approach. J Appl Phycol 30:1563-1574. https://doi.org/10.1007/s10811-017-1348-3

Decho AW, Gutierrez T (2017) Microbial extracellular polymeric substances (EPSs) in ocean systems. Front Microbiol 8:1-28. https://doi.org/10.3389/ fmicb.2017.00922

Dejsungkranont M, Chisti Y, Sirisansaneeyakul S (2017) Simultaneous production of C-phycocyanin and extracellular polymeric substances by photoautotrophic cultures of Arthrospira platensis. J Chem Technol Biotechnol 92:2709-2718. https://doi.org/10.1002/jctb.5293

Delattre C, Pierre G, Laroche C, Michaud P (2016) Production, extraction and characterization of microalgal and cyanobacterial exopolysaccharides. Biotechnol Adv 34:1159-1179. https://doi.org/10.1016/j.biotechadv .2016.08.001

Depraetere O, Deschoenmaeker F, Badri H, Monsieurs P, Foubert I, Leys N, Wattiez R, Muylaert K (2015) Trade-off between growth and carbohydrate accumulation in nutrient-limited Arthrospira sp. PCC 8005 studied by integrating transcriptomic and proteomic approaches. PLOS ONE 10:e0132461. https://doi.org/10.1371/journal.pone.0132461

Du Z, Li Y, Wanga X, Wana Y, Chen Q, Wang C, Lin X, Liu Y, Chen P, Ruan R (2012) Microwave-assisted pyrolysis of microalgae for biofuel production. Bioresour Technol 102:4890-4896. https://doi.org/10.1016/j.biort ech.2011.01.055

Dubois M, Gilles KA, Hamilton JK, Rebers PA, Smith F (1956) Colorimetric method for determination of sugars and related substances. Anal Chem 28:350-356. https://doi.org/10.1021/ac60111a017

George EA (1976) Culture centre of algae and protozoa: list of strains 1976, 3rd ed. Institute of Terrestrial Ecololy, Natural Environment Research Council, Cambridge

Gong H, Tang Y, Wang J, Wen X, Zhang L, Lu C (2008) Characterization of photosystem II in salt-stressed cyanobacterial Spirulina platensis cells. Biochim Biophys Acta 1777:488-495

Goo BG, Baeka G, Choi DJ, Park YI, Synytsyac A, Bleha R, Seong DH, Lee CG, Park JK (2013) Characterization of a renewable extracellular polysaccharide from defatted microalgae Dunaliella tertiolecta. Bioresour Technol 129:343-350. https://doi.org/10.1016/j.biortech.2012.11.077

Han P, Suna Y, Jiaa S, Zhonga C, Tan Z (2014) Effects of light wavelengths on extracellular and capsular polysaccharide production by Nostoc flagelliforme. Carbohydr Polym 105:145-151. https://doi.org/10.1016/j.carbp ol.2014.01.06

Hussein MH, Abou-elwafa GS, Shaaban-dessuuki SA, Hassan NI (2015) Characterization and antioxidant activity of exopolysaccharide secreted by Nostoc carneum. Int J Pharmacol 11:432-439. https://doi.org/10.3923/ ijp.2015.432.439

Li H, Mao W, Hou Y, Gao Y, Qi X, Zhao C, Chen Y, Chen Y, Li N, Wang C (2012) Preparation, structure and anticoagulant activity of a low molecular weight fraction produced by mild acid hydrolysis of sulfated rhamnan from Monostrom alatissimum. Bioresour Technol 114:414-418. https://doi. org/10.1016/j.biortech.2012.03.025

Lowry OH, Rosebrough NJ, Farr AL, Randall RJ (1951) Protein measurement with the Folin phenol reagent. J Biol Chem 193:265-275

Lupi FM, Fernandes HML, Tomé MM, Sá-Correia I, Novais JM (1994) Influence of nitrogen source and photoperiod on exopolysaccharide synthesis by the microalga Botryococcus braunii UC 58. Enzym Microb Technol 16:546-550. https://doi.org/10.1016/0141-0229(94)90116-3

Manirafasha E, Murwanashyaka T, Ndikubwimana T, Ahmed RN, Liu J, Lu Y, Zeng X, Ling X, Jing K (2018) Enhancement of cell growth and phycocyanin production in Arthrospira (Spirulina) platensis by metabolic stress and nitrate fed-batch. Bioresour Technol 255:293-301. https://doi. org/10.1016/j.biortech.2017.12.068

Markou G, Angelidaki I, Georgakakis D (2012) Microalgae carbohydrates: an overview of the factors influencing carbohydrates production and of main bioconversion technologies for production of biofuels. Appl Microbiol Biotechnol 96:631-645. https://doi.org/10.1007/s00253-012-4398-0

Miklestad SM (1995) Release of extracellular products by phytoplankton with special emphasis on polysaccharides. Sci Total Environ 165:155-164. https ://doi.org/10.1016/0048-9697(95)04549-G

Mishra A, Jha B (2009) Isolation and characterization of extracellular polymeric substances from micro-algae Dunaliella salina under salt stress. Bioresour Technol 100:3382-3386. https://doi.org/10.1016/j.biortech.2009.02.006

Mishra A, Kavita K, Jha B (2011) Characterization of extracellular polymeric substances produced by micro-algae Dunaliella salina. Carbohydr Polym 83:852-857. https://doi.org/10.1016/j.carbpol.2010.08.067

Mouhim FR, Cornet J, Fontane T, Fournet B, Dubertret G (1993) Production, isolation and preliminary characterization of the exopolysaccharide of the cyanobacterium Spirulina platensis. Biotechnol Lett 15:567-572. https ://doi.org/10.1007/BF00138541

Mundt S, Kreitlow S, Nowotny A, Effmert U (2001) Biochemical and pharmacological investigations of selected cyanobacteria. Int J Hyg Environ Health 203:327-334. https://doi.org/10.1078/1438-4639-00045

Nouha K, Kumar RS, Balasubramanian S, Tyagi RD (2018) Critical review of EPS production, synthesis and composition for sludge flocculation. J Environ Sci 66:225-245. https://doi.org/10.1016/j.jes.2017.05.020

Ohki K, Le N, Yoshikawa S, Kanesaki Y, Okajima M, Kaneko T, Thi T (2014) Exopolysaccharide production by a unicellular freshwater cyanobacterium Cyanothece sp. isolated from a rice field in Vietnam. J Appl Phycol 26:265-272. https://doi.org/10.1007/s10811-013-0094-4

Oliver JWK, Atsumi S (2014) Metabolic design for cyanobacterial chemical synthesis. Photosynth Res 120:249-261. https://doi.org/10.1007/s1112 0-014-9997-4

Otero A, Vincenzini M (2003) Extracellular polysaccharide synthesis by Nostoc strains as affected by $\mathrm{N}$ source and light intensity. J Biotechnol 102:143-152. https://doi.org/10.1016/s0168-1656(03)00022-1

Ozturk S, Aslim B (2010) Modification of exopolysaccharide composition and production by three cyanobacterial isolates under salt stress. Environ Sci. Pollut Res 17:595-602. https://doi.org/10.1007/s11356-009-0233-2

Parikh A, Madamwar D (2006) Partial characterization of extracellular polysaccharides from cyanobacteria. Bioresour Technol 97:1822-1827. https:// doi.org/10.1016/j.biortech.2005.09.008

Pereira S, Zille A, Micheletti E, Moradas-Ferraira P, De Philippis R, Tamagnini P (2009) Complexity of cyanobacterial exopolysaccharides: composition, structures, inducing factors and putative genes involved in their biosynthesis and assembly. FEMS Microbiol Rev 33:917-941. https://doi.org/10.1 111/j.1574-6976.2009.00183.x

Piedras FR, Baisch PRM, Machado MICS, Vieira AAH, Giroldo D (2010) Carbohydrate release by a subtropical strain of Spondylosium pygmaeum (Zygnematophyceae): influence of nitrate availability and culture aging. J Phicol 46:477-483. https://doi.org/10.1111/j.1529-8817.2010.00823.x

Pignolet O, Jubeau S, Vacca Garcia C, Michaud P (2013) Highly valuable microalgae: biochemical and topological aspects. J Ind Microbiol Biotechnol 40:781-796. https://doi.org/10.1007/s10295-013-1281-7

Reichert M, Bergmann SM, Hwang J, Buchholz R, Lindenberger C (2017) Antiviral activity of exopolysaccharides from Arthrospira platensis against koi herpesvirus. J Fish Dis. https://doi.org/10.1111/jfd.12618

Santos RR, Corrêa PS, Dantas FML, Teixeira CMLL (2019) Evaluation of the co-production of total carotenoids, C-phycocyanin and polyhydroxyalkanoates by Arthrospira platensis. Bioresour Technol Rep 7:100226. https:// doi.org/10.1016/j.biteb.2019.100226 
Shabana EF, Gabr MA, Moussa HR, El-Shaer EA, Ismaiel MMS (2017) Biochemical composition and antioxidant activities of Arthrospira (Spirulina) platensis in response to gamma irradiation. Food Chem 214:550-555. https:// doi.org/10.1016/j.foodchem.2016.07.109

Su C, Chi Z, Lu W (2007) Optimization of medium and cultivation conditions for enhanced exopolysaccharide yield by marine Cyanothece. Chin J Oceanol Limnol 25:411-417. https://doi.org/10.1007/s00343-007-0411-3

Trabelsi L, M'sakni NH, Ouada HB, Roudesli S (2009a) Partial characterization of extracellular polysaccharides produced by cyanobacterium Arthrospira platensis. Biotechnol Biopr Eng 14:27-31. https://doi.org/10.1007/s1225 7-008-0102-8

Trabelsi L, Ouada HB, Bacha H (2009b) Combined effect of temperature and light intensity on growth and extracellular polymeric substance production by the cyanobacterium Arthrospira platensis. J Appl Phycol 21:405-412. https://doi.org/10.1007/s10811-008-9383-8

Trabelsi L, Chaieb O, Mnari A, Abid-Essafi S, Aleya L (2016) Partial characterization and antioxidant and antiproliferative activities of the aqueous extracellular polysaccharides from the thermophilic microalgae Graesiellas p. BMC Complement Altern Med 16:2-10. https://doi.org/10.1186/s1290 6-016-1198-6
Villay A, Laroche C, Roriz C, El Alaoui H, Delbac F, Michaud P (2013) Optimisation of culture parameters for exopolysaccharides production by the microalga Rhodella violacea. Bioresour Technol 146:732-735. https://doi. org/10.1016/j.biortech.2013.07.030

Wingender J, Neu RT, Flemming HC (1999) Microbial extracellular polymeric substances, vol 1. Springer-Verlag, Berlin, pp 1-19

Xiao R, Yang X, Lic M, Lia X, Weib Y, Caod M, Ragauskasc A, Thiesg M, Dingg J, Zhenga $Y$ (2018) Investigation of composition, structure and bioactivity of extracellular polymeric substances from original and stress-induced strains of Thraustochytrium striatum. Carbohydr Polym 195:515. https:// doi.org/10.1016/j.carbpol.2018.04.126

\section{Publisher's Note}

Springer Nature remains neutral with regard to jurisdictional claims in published maps and institutional affiliations.

\section{Submit your manuscript to a SpringerOpen ${ }^{\odot}$ journal and benefit from:}

- Convenient online submission

- Rigorous peer review

- Open access: articles freely available online

- High visibility within the field

- Retaining the copyright to your article

Submit your next manuscript at $\boldsymbol{\sim}$ springeropen.com 